\title{
Reappearance of Galerix (Erinaceomorpha, Mammalia) at the Middle to Late Miocene transition in South Germany: biostratigraphic and palaeoecologic implications
}

\author{
Jérôme Prieto ${ }^{1,2,4}$, Lars W. van den Hoek Ostende ${ }^{3}$, Madelaine Böhme \\ ${ }^{1}$ Senckenberg Center for Human Evolution and Paleoecology (HEP), Eberhard-Karls University Tuebingen, Insti- \\ tute for Geoscience, Sigwartstr. 10, D-72076 Tübingen, Germany \\ ${ }^{2}$ Department for Earth and Environmental Sciences, Section Palaeontology, Ludwig-Maximilians-University \& \\ Bavarian State Collection, Munich, Richard-Wagner-Str. 10, 80333 Munich, Germany \\ ${ }^{3}$ Netherlands Centre for Biodiversity Naturalis, P.O. Box 9517, 2300 RA Leiden, The Netherlands \\ ${ }^{4}$ E-mail: j.prieto@lrz.uni-muenchen.de
}

Key words: climate fluctuation, Erinaceidae, Miocene, Northern Alpine Foreland Basin

\begin{abstract}
The presence of Galerix molars in the South German fossil locality Hammerschmiede 3 is interpreted as evidence for a reimmigration of West European origin into the North Alpine Foreland Basin at the transition of the Middle to Late Miocene. The brief re-appearence of Galerix in southern Germany can be used as a biostratigraphic marker that allows promising correlations between local biostratigraphic subdivisions from Spain and Germany, suggesting that, contrary to previous thought, the Hammerschmiede locality may antedate the hipparionine horses' appearance event. Based on the supposed climatic adaptation of galericine taxa and lower vertebrate record, it is hypothesized that short term climatic fluctuations occurred in South Germany around the time of the first appearance of the hipparionine horses in Europe.
\end{abstract}

\section{Contents}

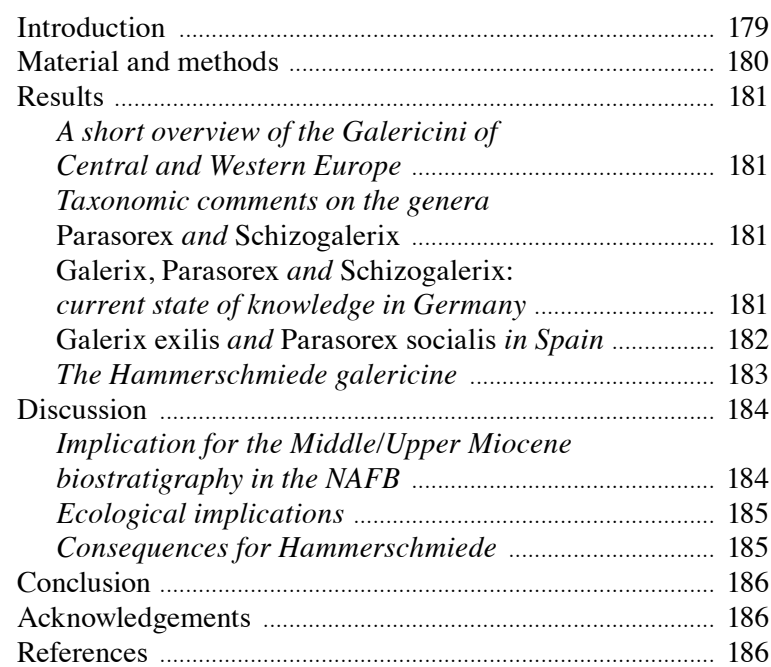

\section{Introduction}

The Middle Miocene is characterized by major global climate changes, including the end of the Miocene climatic optimum (Böhme, 2003) due to global cooling (Shevenell et al., 2004). In Europe, the end of the Middle Miocene is subjected to an aridity peak, followed by warm conditions and considerably more precipitation than present during the Tortonian ('washhouse' climatic phases, Böhme et al., 2008). Coincident with these climatic events, a major reorganization in the European mammal faunas takes place (CasanovasVilar et al., 2010). For instance, a new wave of hominoids entered Europe (Casanovas-Vilar et al., 2008a).

From a biostratigraphical perspective, the most important immigrants at the boundary between Middle and Late Miocene are the hipparionine horses. The transition from Middle to Late Miocene is well documented in Spain, in sections with both large and small mammals in the Daroca-Calamocha area of the Teruel Basin (Álvarez Sierra et al., 2003), and the VallésPenedés Basin (Casanovas-Vilar et al., 2006; Casanovas-Vilar, 2007). Unfortunately, the entrance of these perissodactyls is not accompanied with major changes in the small mammal faunas (Casanovas-Vilar et al., 2010).

In sharp contrast to the Spanish record, the transition from Middle to Late Miocene is poorly documented in Germany and in Central Europe in general. This hampers correlations through Europe and thus the understanding of large scale patterns in faunal distribution. The German locality Hammerschmiede is one of the few small mammal localities of North Alpine 
Foreland Basin (NAFB) that represents this time interval. Traditionally, it is placed in MN 9 (earliest Late Miocene), but as no Hipparion s.l. was found in the locality, there is no direct evidence for this designation. In the NAFB, the period is marked by the end of the molasse sedimentation (Frisch et al., 1999), the uplift of the southern part of the Bohemian massive (Ziegler and Dèzes, 2007), the uplift of the eastern Alps (Kuhleman, 2007) and change in the fluvial direction in the basin from originally east-west to west-east. Hammerschmiede sediments (Fig. 1, $6 \mathrm{~km}$ NNW of Kaufbeuren, Germany, see Mayr and Fahlbusch (1975) for details) derive from to the youngest deposits of the Upper Freshwater Molasse (UFM) of the NAFB. These deposits are referred to as the Obere Serie (Doppler, 1989; Doppler et al., 2005), which is biostratigraphically defined by the presence of the largesized Deinotherium giganteum Kaup, 1829 (Dehm, 1955). The UFM deposits of Hammerschmiede are known for their rich fossil content, dominated by small mammals, ectothermic tetrapods and fishes (fossil layer 1, Mayr and Fahlbusch, 1975; Fahlbusch and Mayr, 1975; Prieto and Rummel, 2009b). The layer of Hammerschmiede 3 corresponds to an erosional channel rich in lignitic pebbles near the top of the sequence.

In the absence of a link with the entrance of the hipparionine horses, mammal palaeontologists had to come up with another marker for MN 9 (Mammal Neogene, De Bruijn et al., 1992; Mein, 1999), the first mammal unit of the Late Miocene. The presence of the highly specialized cricetid rodent Microtocricetus molassicus Fahlbusch and Mayr, 1975 in Hammerschmiede (Fahlbusch and Mayr, 1975; Mayr and Fahlbusch, 1975) is the usual argument to place the locality in $\mathrm{MN} 9$ as the species is traditionally considered as to be typical for this faunal unit in Central and Eastern Europe (De Bruijn et al., 1992: 70; Mein, 1999).

The discovery of Galerix molars in Hammerschmiede 3 is remarkable. The genus was believed to have become extirpated in the region halfway the Middle Miocene (Ziegler, 2006a), while surviving up to the Late Miocene in Spain (Van den Hoek Ostende, 2001; Van den Hoek Ostende and Furió, 2005). Given the good record of the latter part of the Middle Miocene in Germany, we have to assume that Galerix remigrated into the region. In this paper we explore the stratigraphical and environmental conclusions that can be drawn from this unexpected re-occurrence of the gymnure.

\section{Material and methods}

The descriptive terminology for Erinaceidae molars follows Engesser (1980). The orientation of the elements for measuring is after Prieto et al. (2010a).

The systematics of the Galericinae follows Van den Hoek Ostende (2001) and Doukas and Van den Hoek Ostende (2006), except that Tetracus is considered a separate genus (Hugueney and Adrover, 2003; Van den Hoek Ostende, 2003). All teeth sizes are given in mm and all figured teeth are shown in left orientation. The

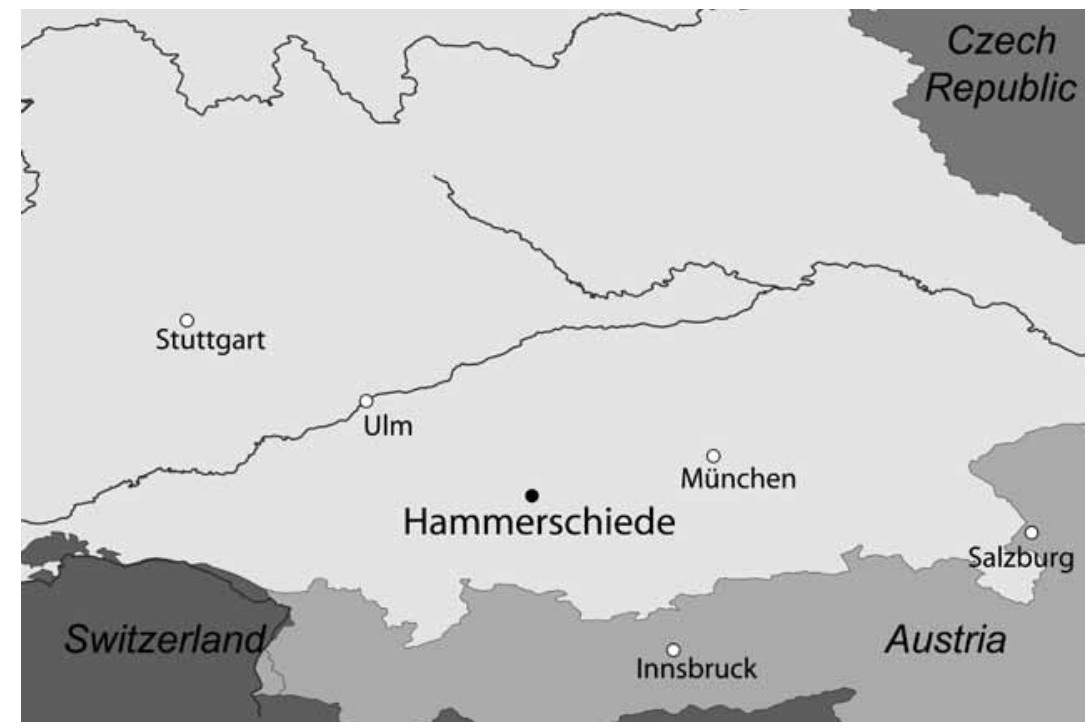

Fig. 1. Geographical map of southern Germany demonstrating the position of the studied locality. 
material comprises of 50 isolated teeth (2 D3, 3 P3, 5 P4, 7 M1, 10 M2, 3 M3, 2 p2, 1 p3, 3 p4, 8 m1 (all damaged or corroded), $3 \mathrm{~m} 2,3 \mathrm{~m} 3$ ) and is stored in the Bayerische Staatssammlung für Paläontologie und Geologie in Munich (BSPG) under the reference numbers 1980 XXVIII 59 to 108.

The separation of the mammal 'zones' MN 7 and MN 8 follows the concept of Kälin et al. (2001).

\section{Results}

\section{A short overview of the Galericini of Central and Western Europe}

Before discussing the Galerix fossils from Hammerschmiede and their biogeographical and stratigraphical consequences, we first present the current state of knowledge of the Galericini record in Central Europe and Spain. Before we can go into that, however, we need to note that there still is an important taxonomical problem that needs to be resolved.

Taxonomic comments on the genera Parasorex and Schizogalerix

The evolutionary history of Schizogalerix, as well as the systematic attribution of the oldest species either to Schizogalerix, Parasorex or Galerix, are still under debate (Van den Hoek Ostende, 2001; Ziegler, 2003, 2005; Doukas and Van den Hoek Ostende, 2006). In contemporary taxonomic interpretations, Schizogalerix is not recorded in the late Middle/earliest Late Miocene (MN 7/8, MN 9) deposits from Western Europe (Spain, France). It is, however, important to note that the Spanish Parasorex material shares some similarities with Schizogalerix, as recorded in Central Europe (Engesser, 1980; Kälin and Engesser, 2001), especially the configuration of the mesostyle of the M1 and M2 (cf. De Jong, 1988: pl. 1, figs 4, 6; Engesser, 1980: fig. 4b). This suggests possible differences in the taxonomical interpretation between western European and central/eastern European scholars, at least concerning the species Parasorex socialis and $S$. voesendorfensis. In the following, if not specified, P. socialis will be understood as proposed in Van den Hoek Ostende (2001).

We include the specimens from Jamm (Austria), originally described as Galerix exilis (Thenius, 1949) and later interpreted as Parasorex socialis (Ziegler and Daxner-Höck, 2005; Ziegler, 2006a), into Schizo- galerix, based on the strong posterior cingulum that directly joins the entoconid on the $\mathrm{m} 1$ and $\mathrm{m} 2$, and the morphology of the mesostyle. Rzebik-Kowalska and Lungu (2009) record the presence of Parasorex socialis in the Moldavian MN 10 locality of Kejnar. No M1 or M2 was found, so the identification was based on the absence of a connection between the posterior cingulum and the entoconid on $\mathrm{m} 1$ and $\mathrm{m} 2$. However, their illustrations (o.c., figs 4e-f) show that this connection was indeed present, thus refuting the identification as $P$. socialis. The Kejnar assemblage is very interesting, as its galericine is more primitive than the Schizogalerix of Buzor 1, a locality that the authors correlate to MN 9.

Although Parasorex socialis is reported in literature from the upper part of the Middle Miocene in Romania (Feru et al., 1979, 1980) and Serbia (Markovic, 2003), the specimens are not described in detail, so their identity cannot be checked. Thus, the presence of $P$. socialis east from the NAFB has not been convincingly demonstrated.

Regardless of the generic attribution of the Spanish Parasorex material, the immigration of Schizogalerix into the NAFB must have come from the eastern part of Europe/Anatolia, as is evident from the good fossil record in the larger part of Middle Miocene from the Turkey (Engesser, 1980; Selänne, 2003). In the Middle Miocene, Schizogalerix anatolica is known from Mátraszölös (Hungary, Gál et al., 1999). Some specimens are also recorded in the Middle Miocene from Greece (Doukas, 2005), MN 9 from Slovakia (Sabol et $a l ., 2004$, and see references in Fejfar and Sabol, 2005), and MN 9 from Moldova (Rzebik-Kowalska and Lun$\mathrm{gu}, 2009)$. The genus is also present in the early Sarmatian of Rumania in Tăşad (Mészáros, written communication in Hír et al., 2001).

Galerix, Parasorex and Schizogalerix: current state of knowledge in Germany

The first representatives of Galericini are recorded in Germany in the MN 3 fissure fillings of the Swabian and Franconian Alb and in Frankfurt/Nordbasin (Ziegler et al.,2005). Most of this material is identified as Galerix aurelianensis, but some smaller specimens have been questionably attributed to G. symeonidisi. In MN 4 fissure fillings, G. aurelianensis certainly coexists with G. symeonidisi, whereas in contemporaneous stratified localities of the NAFB only the latter species is found (e.g., locality Raucheröd, Ziegler and Fahlbusch, 1986). In MN 5 localities, all from fluviatil 
deposits, one Galericini species is recorded, which is incorporated by Ziegler and Fahlbusch (1986) into the G. symeonidisi-G. exilis lineage. Van den Hoek Ostende and Doukas (2003) do not recognize this lineage in Spain and proposed that G. exilis gradually replaced the G. symeonidisi (comments in Ziegler, 2005: 138). Scarce evidence of G. aurelianensis-like forms is recorded from the late Karpatian of Sandelzhausen (Ziegler, 2000) and possibly Maßendorf (Galerix sp. in Schötz, 1988). In MN 6 localities (stratified and fissures; e.g. locality Goldberg, Ziegler 1983) G. exilis is mostly the only Galericini. A larger Galerix species was recently described in the fissure filling Petersbuch 68 (probably latest MN 6, Prieto and Rummel, 2009a).

Parasorex socialis is recorded from both fissure fillings (Ziegler, 2005) and stratified localities in MN 7 and 8, such as Steinheim, Anwil, Kleineisenbach and Giggenhausen (Engesser, 1972; Prieto, 2007).

At the base of the MN 9, Schizogalerix voesendorfensis (Rabeder, 1973) co-occurs with Schizogalerix sp. in the Swiss locality Nebelbergweg (Kälin and Engesser, 2001). Ziegler et al. (2005) and Ziegler (2006a) listed $P$. socialis in the MN 9 faunas from Aumeister and Grosslappen near Munich. Much of the original material from these localities, published by Stromer (1940), was lost during the World War II. On the basis of the remaining fossils stored in the BSPG, we find no evidence for the presence of $P$. socialis in MN 9 localities. The material from Grosslappen is too poorly preserved (BSPG 1927 VIII 20, 1933 IV 44) to be confidently identified. According to us, the well-preserved mandible from Aumeister belongs to the genus Schizogalerix, as is indicated by the strong posterior cingulum that directly joins the entoconid on the $\mathrm{m} 1$ and $\mathrm{m} 2$. The sizes of the teeth $(\mathrm{p} 3: \mathrm{L}: 1.86 \times \mathrm{W}: 0.98 ; \mathrm{p} 4: \mathrm{L}$ : $2.03 \times \mathrm{W}: 1.55 ; \mathrm{m} 1: \mathrm{L}: 3.00 \times \mathrm{W} 1: 1.79 \times \mathrm{W} 2: 2.01 ; \mathrm{m} 2$ : L: $2.30 \times \mathrm{W} 1: 1.79 \times \mathrm{W} 2: 1.84)$ agree with those of Schizogalerix sp. from Nebelbergweg (Kälin and Engesser, 2001).

\section{Galerix exilis and Parasorex socialis in Spain}

The first occurrence of Parasorex socialis in Spain is in the Vallès-Penedès Basin in San Quirze, a locality that is correlated to the Megacricetodon ibericus Democricetodon crusafonti Zone (corresponding to the MN 8 sensu Mein and Ginsburg 2002, CasanovasVilar et al., 2008a). This zone extends from 11.9-11.5 to $10.9 \mathrm{Ma}$ (Casanovas-Vilar et al., 2008b) and may correspond to the upper part of the zone G3 of the Calatayud-Daroca and Teruel Basins (Casanovas-Vilar, 2007). Galerix exilis is not recorded in the VallèsPenedès. Parasorex socialis is also documented in the Teruel basin with its first occurrence in Nombrevilla 2 (11.5 Ma in Daams et al., 1999; 11.69 Ma in Van Dam et al., 2006).

The presence of Galerix exilis in the DarocaCalatayud area of the Teruel Basin was noted by De Jong (1988), who described material from the late

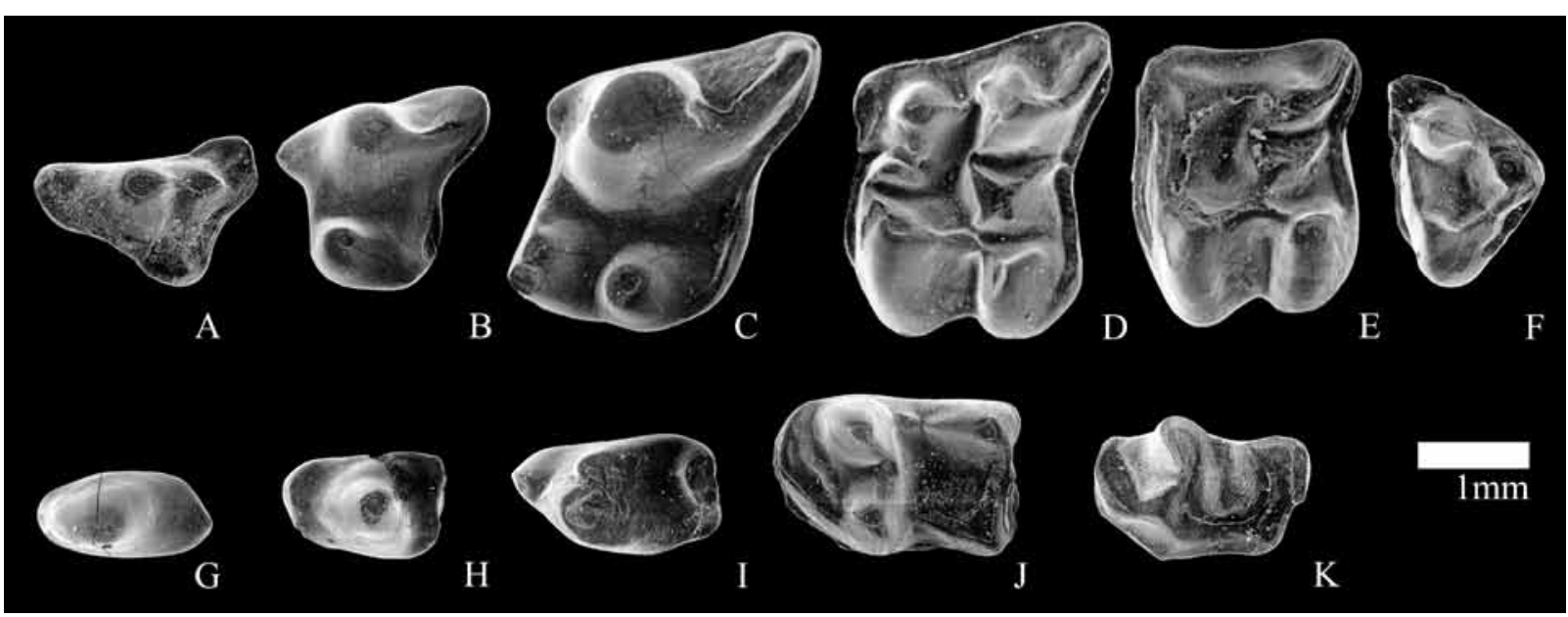

Fig. 2. Galerix cf. exilis (de Blainville, 1839) from Hammerschmiede 3. A: right D3 ( inversed, BSPG 1980 XXVIII 59); B: right P3 (inversed, BSPG 1980 XXVIII 60); C: right P4 (inversed, BSPG 1980 XXVIII 61); D: left M1 (BSPG 1980 XXVIII 61); E: right M2 (inversed, BSPG 1980 XXVIII 63); F: right M3 (inversed, BSPG 1980 XXVIII 64); G: left p2 (BSPG 1980 XXVIII 65); H: left p3 (BSPG 1980 XXVIII 66); I: left p4 (BSPG 1980 XXVIII 67); J: left m2 (BSPG 1980 XXVIII 68); K: right m3 (inversed, BSPG 1980 XXVIII 69). 
Middle Miocene. The species was present earlier, and, according to Van den Hoek Ostende and Doukas (2003), gradually replaced G. symeonidisi. The older material of G. exilis has not yet been described in detail, and the entire sequence is currently under study. According to Van den Hoek Ostende and Doukas (2003: Figs 1-2), the species is certainly present from zone D upwards (MN 5). The last occurrence of $G$. exilis depends on the dating of Carrilanga 1 (10.5 Ma according to Daams et al., 1999, 11.57 Ma according to Van Dam et al., 2006). As the biostratigraphic correlation of Carrilanga proves to be so difficult we place the last occurrence of G. exilis in Spain at 11.5 Ma, based on its occurrence in Nombrevilla 2, pending ongoing research of the Museo Nacional de Ciencias Natureles (Madrid) on the Aragonian/Vallesian sections in the area.

\section{The Hammerschmiede galericine}

Figure 2 shows a selection of the molars from the Hammerschmiede gymnure. The upper molars, which are clearly wider than long and posses a distinct, crescent-shaped metaconule, identify the Hammerschmiede gymnure as a member of the Galericini. Because most of the M1 (five out of eight) and M2 (one out of two) have a short posterior arm of the metaconule, the P3 have one lingual cusp, and there is no division of the mesostyle in the M1 and M2, the material must be attributed to Galerix (Van den Hoek Ostende, 2001).

Since a substantial fraction of the molars are worn in our sample, the relative abundance of specimens having a protocone-metaconule connection on M1/M2 is difficult to establish. Most of the specimens do not have this ridge complete, but it is often incipiently present. On one considerably damaged M2, the protocone-metaconule connection is present and the hypocone is isolated. The connection of the posterior arm of the metaconule with the posterior cingulum, if present, is weak. The metaconid of the single unworn p4 is about half the height of the protoconid. On the two other specimens, the metaconid seems to be relatively high due to the abrasion of the teeth. The cuspids are worn on their posterior side.

One M1 from Hammerschmiede (Fig. 2D) has a curved anterior arm of the protocone, so that the anterior part of the molar seems to be compressed in comparison with the other specimens. Given the limited number of molars, this tooth is here interpreted as an aberrant specimen.
Compared to Galerix exilis from older localities in southern Germany (Ziegler, 1983), and from the type locality Sansan (Engesser, 2009), the Hammerschmiede 3 assemblage differs in having a long posterior arm of the metaconule on several M1 and M2 (three out of eight M1, one out of two M2). It also differs in the morphology of the P3, as the three preserved premolars from Hammerschmiede 3 have a better-developed lingual part of the tooth. Furthermore, the parastyle and the posterior arm of the para-

Table 1. Measurements of Galerix cf. exilis from Hammerschmiede 3.

\begin{tabular}{|c|c|c|c|c|}
\hline & L or L1 & L2 & W or W1 & W2 \\
\hline D3 & 2.06 & & 1.09 & \\
\hline D3 & 2.01 & & 1.23 & \\
\hline P3 & 1.98 & & 1.74 & 1.66 \\
\hline P3 & 1.76 & & 1.54 & 1.64 \\
\hline P4 & 2.40 & & 2.33 & 2.74 \\
\hline $\mathrm{P} 4$ & 2.38 & & 2.30 & 2.40 \\
\hline $\mathrm{P} 4$ & 2.61 & & 2.48 & 2.63 \\
\hline P4 & 2.19 & & 2.38 & 2.45 \\
\hline M1 & 2.70 & & 2.80 & 3.05 \\
\hline M1 & 2.35 & & 2.53 & 2.81 \\
\hline M1 & 2.51 & & 2.68 & 3.05 \\
\hline M1 & 2.54 & & 2.80 & 3.18 \\
\hline M1 & 2.63 & & 2.73 & 3.16 \\
\hline M1 & 2.41 & & 2.65 & 3.00 \\
\hline M1 & 2.66 & & 2.95 & 3.18 \\
\hline M1 & 2.48 & & 2.73 & 3.09 \\
\hline M2 & 2.01 & & 2.64 & 2.53 \\
\hline M2 & 2.06 & & 2.78 & 2.48 \\
\hline M3 & 1.65 & 1.39 & 2.06 & \\
\hline M3 & 1.38 & 1.15 & 1.84 & \\
\hline M3 & 1.51 & 1.39 & 1.94 & \\
\hline p2 & 1.45 & & 0.73 & \\
\hline p2 & 1.68 & & 0.85 & \\
\hline p3 & 1.61 & & 1.08 & \\
\hline p4 & 2.05 & & 1.21 & \\
\hline p4 & 2.08 & & 1.18 & \\
\hline $\mathrm{m} 2$ & 2.31 & & 1.40 & 1.45 \\
\hline $\mathrm{m} 2$ & 2.39 & & 1.63 & 1.54 \\
\hline $\mathrm{m} 2$ & 2.35 & & 1.68 & 1.63 \\
\hline $\mathrm{m} 3$ & 1.90 & & 1.20 & \\
\hline $\mathrm{m} 3$ & 1.80 & & 1.30 & \\
\hline
\end{tabular}


cone are smaller on $\mathrm{P} 3$ and $\mathrm{P} 4$. The $\mathrm{p} 2$ and $\mathrm{p} 3$ are about the same length as the teeth from Goldberg and Steinberg, but are somewhat wider. The specimens from Hammerschmiede agree in overall size and morphology with G. exilis from Solera, a locality representing the latest Middle Miocene in east Central Spain (De Jong, 1988), and are thus assigned to G. cf. exilis. The measurements for the Hammerschmiede Galerix are given in Table 1.

\section{Discussion}

Implication for the Middle/Upper Miocene biostratigraphy in the NAFB

The first occurrence of hipparionine horses in Europe defines the beginning of MN 9 (e.g., Mein, 1999). In the Vallès-Penedès Basin (Catalonia, Spain) the oldest occurrence of Hipparionine horses is in the locality of Creu Conill 22 in the Can Guitar 1 section, and is correlated to the base of the chron C5r.1n, about $11.1 \mathrm{Ma}$ (Garcés et al., 1996, 2003; Casanovas-Vilar et al., 2006). This is somewhat older than the estimate for the first occurrence of hipparionine horses in the DarocaCalatayud area in Central Spain (10.7-10.8 Ma in Garcés et al.,2003) and slightly younger than the estimated age of this event in Austria (11.2 Ma in DaxnerHöck, 1996; Rögl and Daxner-Höck, 1996). In the NAFB Hippotherium primigenium is rare, reported only from the large mammals localities Charmoille (Kälin, 1993), Lugnez (Erzinger, 1943), Hausruck (Thenius, 1952) and Höwenegg (e.g., Tobien, 1938, 1982). The latter fossil locality is dated $10.3 \mathrm{Ma}$ (Steininger et al., 1996: 14) to $10.8+/-0.4 \mathrm{Ma}$ (Baranyi et al., 1976; Becker-Platen et al., 1977).

Thus, the presence of Galerix cf. exilis challenges the validity of the earliest Late Miocene correlation of Hammerschmiede 3. We propose that Galerix must have entered the NAFB before its extinction in Spain, i.e., before or at least at $11.5 \mathrm{Ma}$ (the age of Nombrevilla 2). The alternative scenario, in which Galerix survived in France in between its extirpation in Spain and entrance into the NAFP is deemed highly unlikely, but cannot be precluded given the current knowledge of the French fossil record.

Following this interpretation, there is no strong argumentation against Hammerschmiede being older than the first appearance of Hippotherium in the NAFB. However, this inference challenges the biostratigraphic value of Microtocricetus and the relative dating of some fossil faunas (see complementary discussion in Prieto et al., 2010b).

Correlating Hammerschmiede to the late Middle Miocene may also have consequences for the correlation of other localities in the NAFB. Based on the evolutionary stage of the cricetid rodent Collimys, Prieto and Rummel (2009b) proposed that Hammerschmiede is older than the Swiss locality of Nebelbergweg, which has also been considered an MN 9 locality (Kälin and Engesser 2001). This correlation is mainly based on the presence of Schizogalerix voesendorfensis in the Swiss locality, because until now the oldest occurrence of Schizogalerix voesendorfensis in Austria was in its type locality (Vösendorf/Inzersdorf), dated between 10.3 and 10.6 Ma (DaxnerHöck, 2004; Ziegler and Daxner-Höck, 2005). Recent discoveries, however, indicate that this species is already present in the late Sarmatian s. str. (late Middle Miocene) of the Styrian Basin (around 12.2 Ma, Prieto et al., 2010a). Thus, the locality of Nebelbergweg cannot unambiguously be correlated to the early Late Miocene. Similarly, the German locality Aumeister cannot be confidently correlated based on Schizogalerix. However, a single Collimys $\mathrm{m} 1$ was found in Aumeister (Fig. 3). This tooth agrees morphologically with $C$. longidens from Nebelbergweg and its size $(1.86 \times 1.21)$ is intermediate between $C$. hiri from Hammerschmiede and $C$. longidens. This suggests that the locality Aumeister is probably slightly younger than Hammerschmiede. Excluding ecological and/or taphonomical bias, it could signify that between the last occurrence of Parasorex socialis (MN

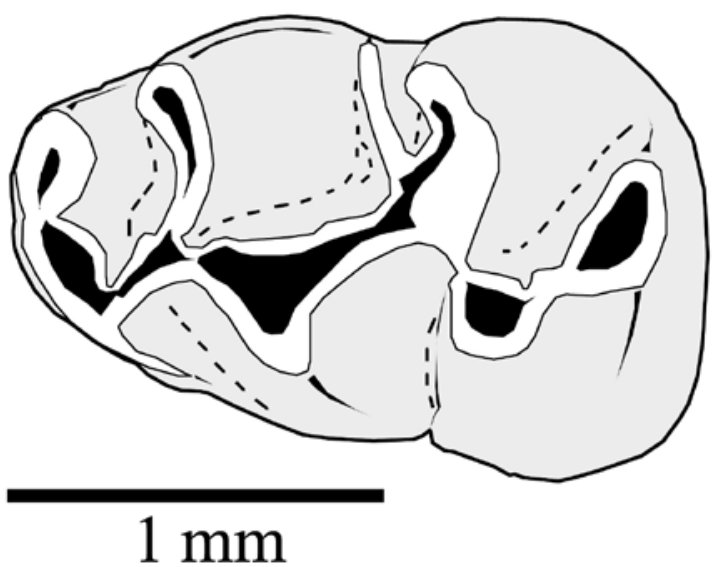

Fig. 3. Collimys cf. longidens Kälin and Engesser, 2001 from Aumeister. Left m1 (BSPG 1926 V 21). 
8; Engesser, 1972; Kälin, 1993; Prieto, 2007) and the first appearance of Schizogalerix in Nebelbergweg, the faunas of the NAFB could have been characterized by Galerix cf. exilis.

\section{Ecological implications}

Assuming that the ecology of the fossil galericines was similar to that of the extant representatives of this subfamily as found in Southeast Asia, they should have been adapted to forest environments close to water (Ziegler, 2005, 2006b). This certainly seems to be true for Lantanotherium, the only member of the subfamily in the European Miocene that is not included in the tribe Galericini (Furió et al., 2011). Lantanotherium often co-occurs with the presumably wateradapted Dimylidae (Plesiodimylus), e.g. in the German locality of Hambach 6C (Ziegler and Mörs, 2000; mean annual precipitation (MAP) $>1100 \mathrm{~mm}, \mathrm{M}$. Böhme unpublished data estimated after the method of Böhme et al., 2006) and of Maßendorf (Schötz, 1988; mean MAP: 887mm, M. Böhme unpublished data), in Devínska Nová Ves - Bonanza (Slovakia, Sabol, 2005), in Tobel Hombrechtikon (Switzerland, Bolliger, 1992), in Götzendorf (Austria, Ziegler, 2006b, MAP: $1.303 \mathrm{~mm}$ (Böhme et al., 2006)) and in Bełchatów B (Poland, Rzebik-Kowalska, 1993, 1996, 2005). Its distribution is mostly restricted to Central Europe. In Spain, the genus is present in the more humid Vallès-Penedès Basin (Casanovas-Vilar and Agusti, 2007; Furió et al., 2011), but absent in the inner basins (Van den Hoek Ostende and Furió, 2005). All indications are that Lantanotherium preferred humid environments.

In contrast, the Galericini seemed to have been more generalists (Furió et al., 2011), as is already indicated by their almost ubiquitous presence in Miocene faunas. Based on functional morphological observations and faunal associations, Van den Hoek Ostende (2001) proposed that Parasorex, Schizogalerix and probably Galerix symeonidisi were adapted to a more herbivorous diet than the other members of the tribe. The preferred habitat of the various species of Galerix has been debated (Van den Hoek Ostende and Doukas, 2003; Van den Hoek Ostende, 2003; Van den Hoek Ostende and Fejfar, 2006). Certainly, Galerix exilis must have been able to cope with dry environments, such as the semiarid climate of the Middle Miocene German localities of Goldberg and Steinberg (Bolten et al., 1976; Ballmann,
1979; Ziegler, 1983) and, e.g. Somosaguas Sur in Spain (Luis and Hernando, 2000). It is one of the few insectivores which remains present in the sections of the Aragonian type-area in Spain following a dramatic decrease in humidity near the boundary of local zones $\mathrm{C}$ and $\mathrm{D}$ at approximately 15.9 Ma (Van der Meulen and Daams, 1992, fig. 7, with age corrected according to Daams et al., 1999).

Based on comparisons of faunal associations of the late Middle Miocene fissure fillings and stratified fossil localities of Germany, Prieto (2007) proposed that Parasorex socialis was not necessarily dependent on humid or forest-covered habitat. The occurrence of $P$. socialis in the NAFB in Steinheim, between 14 to 13.5 Ma, is almost contemporaneous with the local disappearance of Galerix exilis. This could suggest different ecological preferences for the two genera. Nevertheless, Galerix and Parasorex can co-occur in a single locality as shown in La Grive (Mein and Ginsburg, 2002; Maridet, 2003), Petersbuch 68 (Prieto and Rummel, 2009a) and Carrilanga (De Jong, 1988).

Notably, the migration of Parasorex in the NAFB coincides with a global cooling event around 14 to 13.5 Ma (Shevenell et al., 2004; Böhme, 2003). This climatic deterioration resulted in a stronger latitudinal temperature gradient in Europe and marks the beginning of a more distinct climatic zonation on the continent. The thermophilic ectotherms survived only in southern regions (south of $37^{\circ} \mathrm{N}$ palaeolatitude, Böhme, 2003). The cooling event has also been observed in the Teruel Basin (Van der Meulen and Daams, 1992: fig. 7, absolute ages corrected according to Daams et al., 1999). As we noted, Galerix exilis survived here during the late part of the Middle Miocene. It becomes extinct near the boundary between local zones G3 and H, i.e., the Aragonian/Vallesian boundary. This time frame coincides with a minor cooling, at a time that humidity increases again (Van der Meulen and Daams, 1992). Therefore, we postulate that Parasorex socialis (sensu Engesser, 1972) was a cooler temperature adapted faunal element, whereas Galerix exilis probably preferred higher temperatures.

\section{Consequences for Hammerschmiede}

Galerix cf. exilis is a rare element of the fauna from Hammerschmiede 3 and is missing in the two other fossil layers of the locality. Putting aside side the possible effects of taphonomic processes, we can hypothesize:

1] that during the sedimentation of the Hammerschmiede section the climate was somewhat warmer 
and/or dryer and Galerix cf. exilis represents a new immigrant, which was not well established in the faunas. This scenario is in conflict with the high precipitation estimates from the herpetological community of Hammerschmiede (Böhme et al., 2006).

2] that the environment of Hammerschmiede 3 was not optimal for the Galerix cf. exilis, but the (re-) immigration of Galerix in the NAFB occurred somewhat earlier during an episode in which the environment differed from that found at Hammerschmiede. Such an episode presented unfavourable conditions for Parasorex socialis (sensu Engesser, 1972), which lead to its disappearance.

The second hypothesis implies a brief but distinct temperature increase and/or decrease in precipitation between Anwil and Hammerschmiede. Such decrease in precipitation is recorded in the NAFB. Böhme et al. (2008) demonstrate that the mean annual precipitation in the region decreased significantly between 12.7 and 11.5 Ma (Sarmatian). The rare presence of crocodiles in Anwil (Böhme, 2003) shows that there were indeed episodes with increased temperature during the later part of the Middle Miocene.

\section{Conclusion}

Galerix cf. exilis is a short-duration Spanish (re-) immigrant in the NAFB (transient sensu Van der Meulen et al., 2005) and Parasorex socialis a central/ eastern European immigrant into Spain. In this hypothesis Hammerschmiede should be older than the last occurrence of G. exilis in Spain (11. 5 My), and thus should be older than traditionally accepted, probably antedating the Middle to Late Miocene transition. The re-appearance of Galerix in the NAFB suggests climatic fluctuations at the end of the Middle Miocene, leading to temporary warmer and/or dryer conditions. At the actual stage of knowledge 1) we conclude that Schizogalerix appears in the NAFB following the re-entrance of G. exilis, and 2) Microtocricetus can no longer be maintained as marker for MN 9.

Although a revision of the genera Galerix, Parasorex and Schizogalerix is necessary at the European scale, the re-appearance of Galerix cf. exilis in the NAFB is a very promising event in local and largescaled biostratigraphical terms. Indeed, this migration can be correlated with major climatic global events and thus allows us to follow the consecutive faunal interchanges near the limit Middle to Late Miocene.

\section{Acknowledgements}

Our special gratitude goes to Helmuth Mayr (München) for providing the fossil material of Hammerschmiede. The authors also thank August Ilg (Düsseldorf) for providing the map in Fig. 1. We are also grateful to K. Rauscher and G. Rabeder (Wien) for providing the fossils from Jamm. Special thanks go to B. Engesser (Basel), who allowed us a sneak preview in his Sansan manuscript. W. Renema (Leiden), M. Sabol (Bratislava) and three anonymous reviewers are thanked for their useful comments. Anne Blair Gould suggested a number of linguistic improvements, for which we are most grateful. This research received support from the Synthesys Project (http://www.synthesys.info/) at the Netherlands Centre for Biodiversity, Naturalis in Leiden (NL-TAF-619), and DFG grant BO 1550/16.

\section{References}

Álvarez Sierra MA, Calvo JP, Morales J, Alonsa-Zarza A, Azanza B, García Paredes I, Hernandez Fernandez M, Meulen AJ van der, Peláez-Campomanes P, Quiralte V, Salesa MJ, Sánchez IMY, Soria D. 2003. El tránsito AragonienseVallesiense en el área de Daroca-Nombrevilla (Zaragoza, España). Pp. 171-178 in: López-Martinez N, Peláez-Campomanes P, Hernández Fernández M, eds, En torno a fósiles de mamiferos: datación, evolución y paleoambiente. Coloquios de Paleontología, Volumen Extraordinario 1.

Ballmann P. 1979. Fossile Glareolidae aus dem Miozän des Nördlinger Rieses (Aves: Charadriiformes). Bonner Zoologische Beiträge 30: 52-102.

Baranyi I, Lippolt HJ, Todt W. 1976. Kalium-Argon-Alterbestimmungen an tertiären Vulkaniten des OberrheingrabenGebietes: II. Die Altertraverse vom Hegau nach Lothringen. Oberrhein geologische Abhandlungen 25: 41-62.

Becker-Platen JD, Benda L, Steffens P. 1977. Litho- und biostratigraphische Deutung radiometricher Altersbestimmungen aus dem Jungtertiär der Türkei. Geologische Jahrbuch Reihe B 25: 139-167.

Böhme M. 2003. Miocene Climatic Optimum: evidence from Lower Vertebrates of Central Europe. Palaeogeography, Palaeoclimatology, Palaeoecology 195: 389-401.

Böhme M, Ilg A, Ossig A, Küchenhoff H. 2006. New method to estimate paleoprecipitation using fossil amphibians and reptiles and the middle and late Miocene amphibians and reptiles and the middle and late Miocene. Geology 34: 425-428.

Böhme M, Ilg A, Winkelhofer M. 2008. Late Miocene 'washhouse' climate in Europe. Earth and Planetary Science Letters 275: 393-401. doi: 10.1016/j.eps1.2008.09.011

Bolliger T. 1992. Kleinsäugerstratigraphie in der miozänen Hörnlischüttung (Ostschweiz). Documenta Naturae 75: 1-296.

Bolten R, Gall H, Jung W. 1976. Die obermiozäne (sarmatiche) Fossil-Lagerstätte Wendung im Nördlinger Ries (Bayern). Ein Beitrag zur Characterisierung des Riessee-Biotop. Geologische Blätter für Nordost-Bayern 26: 75-94.

Casanovas-Vilar I. 2007. The rodent assemblages from the Late Aragonian and the Vallesian (Middle to Late Miocene) of the Vallès-Penedès Basin (Catalonia, Spain). PhD thesis, Universitat Autònoma de Barcelona. 
Casanovas-Vilar I, Furió M, Agusti J. 2006. Rodents, Insectivores and paleoenvironment Associated to the First-Appearing Hipparione Horses in the Vallès-Penedès Basin (Northeastern Spain). Beiträge zur Paläontologie 30: 89-107.

Casanovas-Vilar I, Agusti G. 2007. Ecogeographical stability and climate forcing in the Late Miocene (Vallesian) rodent record in Spain. Paleogeography, Paleoclimatology, Paleoecology 248: 169-189.

Casanovas-Vilar I, Alba DM, Moyà-Sola S, Galindo J, Cabrera L, Garcés M, Furió M, Robles JM, Köhler M, Angelone M. 2008a. Biochronological, taphonomical and paleoenvironmental background of the fossil great ape Pierolapithecus catalaunicus (Primates, Hominidae). Journal of Human Evolution 55: 589-603.

Casanovas-Vilar I, Garcés M, Galindo J, Cabrera L, Robles JM, Alba DM, Moyà-Sola S, Galindo J, Rotgers C, Carmora R, Almécija S, Bertó Mengual JV, Beamud E. 2008b. Chronology of the recently discovered Middle Miocene primatebearing sites of the Vallès-Penedès Basin (Catalonia, Spain). Abstracts Workshop European fossil primates, Grosseto: 122-123.

Casanovas-Vilar I, García-Paredes I, Alba DM, van den Hoek Ostende LW, Moyà-Solà S. 2010. The European Far West: Miocene mammal isolation, diversity and turnover in the Iberian peninsula. Journal of Biogeography 37: 1079-1093.

Daams R, Meulen AJ van der, Àlvarez Sierra MA, Peláez-Campomanes P, Calvo JP, Alonzo Zarza MA, Krijgsman W. 1999. Stratigraphy and sedimentology of the Aragonian (Early to Middle Miocene) in its type area North-Central Spain). Newsletters on Stratigraphy 37: 103-139.

Daxner-Höck G. 1996. Faunenwandel im Obermiozän und Korrelation der MN-'Zonen' mit den Biozonen des Pannons der Zentralen Paratethys. Beiträge zur Paläontologie 21: 1-9.

Daxner-Höck G. 2004. Flying Squirrels (Pteromyinae, Mammalia) from the Upper Miocene of Austria. Annalen des Naturhistorischen Museums in Wien 106 A: 387-423.

De Bruijn H, Daams R, Daxner-Höck G, Fahlbusch V, Ginsburg L, Mein P, Morales J. 1992. Report on the RCMNS working group on fossil mammals, Reisensburg 1990. Newsletter on Stratigraphy 26: 65-118.

De Jong F. 1988. Insectivora from the Upper Aragonian and Lower Vallesian of the Daroca-Villafeliche area in the Calatayud-Teruel Basin (Spain). Scripta Geologica, Special Issue 1: 253-285.

Dehm R. 1955. Die Säugetier-Faunen in der Oberen Süßwassermolasse und ihre Bedeutung für die Gliederung. Pp. 81-88 in: Bayerisches Geologisches Landesamt, ed., Erläuterungen zur Geologischen Übersichtskarte der Süddeutschen Molasse. München: Bayerisches Geologisches Landesamt.

Doppler G. 1989. Zur Stratigraphie der nördlichen Vorlandmolasse in Bayerisch-Schwaben. Geologica Bavarica 94: 83-113.

Doppler G, Heissig K, Reichenbacher B. 2005. Zur Gliederung des Tertiärs im süddeutschen Molassebecken. Newsletters on Stratigraphy 41: 359-375.

Doukas CS. 2005. Greece. Pp. 99-112 in: van den Hoek Ostende LW, Doukas CS, Reumer JWF, eds, The Fossil Record of the Eurasian Neogene Insectivores (Erinaceomorpha, Soricomorpha, Mammalia), Part I. Scripta Geologica, Special Issue 5 .

Doukas CS, van den Hoek Ostende LW. 2006. Insectivores (Ericeomorpha, Soricomorpha; Mammalia) from Karydia and Komotini (Thrace, Greece; MN 4/5). Beiträge zur Paläontologie 30: 109-131.

Engesser B. 1972. Die obermiozäne Säugertierefauna von Anwil (Baselland). Tätigkeitsberichte der Naturforschenden Gesellschaft Baselland 28: 37-363.

Engesser B. 1980. Insectivora and Chiroptera (Mammalia) aus dem Neogen der Türkei. Schweizerische Paläontologische Abhandlungen 102: 45-149.

Engesser B. 2009. The Insectivores (Mammalia) from Sansan (Middle Miocene, south-western France). Schweizerische Paläontologische Abhandlungen 128: 1-91.

Erzinger E. 1943. Die Oberflächenformen der Ajoie (Berner Jura). Mitteilungen Geographisch Ethnologischen Gesellschaft Basel 5: 1-138.

Fahlbusch V, Mayr H. 1975. Microtoide Cricetiden (Mammalia, Rodentia) aus der Oberen Süßwasser-Molasse Bayerns. Paläontologische Zeitschrift 49: 78-93.

Fejfar O, Sabol M. 2005. Czech Republic and Slovak Republic. Pp. 51-60 in: Van den Hoek Ostende LW, Doukas CS, Reumer JWF, eds, The Fossil Record of the Eurasian Neogene Insectivores (Erinaceomorpha, Soricomorpha, Mammalia), Part I. Scripta Geologica, Special Issue 5.

Feru M, Radulesco C, Samson P. 1979. La faune de Micromammifères du Miocène de Tauţ (dép. d'Arad). Travaux de l'Institut de Spéologie 'Emile Racovitza' XIX: 185-190.

Feru M, Radulesco C, Samson P. 1980. La faune de Micromammifères du Miocène de Comãneşti (dép. d'Arad). Travaux de l'Institut de Spéologie 'Emile Racovitza' XIX: 171-190.

Frisch W, Brügel AJ, Dunkl I, Kuhlemann J, Satir M. 1999. Post-collisional large-scale extension and mountain uplift in the Eastern Alps. Memorie di Scienze Geologiche (Padova) 51: 3-23.

Furió M, Casanovas-Vilar I, van den Hoek Ostende LW. 2011. Predictable structure of Miocene insectivore (Lipotyphla) faunas in Western Europe along a latitudinal gradient. Paleogeography, Paleoclimatology, Paleoecology 304: 219-229. doi: 10.1016/j.palaeo.2010.01.039

Gál E, Hír J, Kessler E, Kókay J. 1999. Középsõ-miocén õsmaradványok, a Mátraszölös, Rákóczi-kápolna alatti útbevágásból. I. A Mátraszõlõs 1. lelõhely [Middle Miocene fossils from the sections at the Rákóczi chapel at Mátraszőlős. Locality Mátraszõlõs I.]. Folia Historico Naturalia Musei Matraensis 23: 33-78.

Garcés M, Agusti J, Cabrera L, Parès JM. 1996. Magnetostratigraphy of the Vallesian (late Miocene) in the VallèsPenedès Basin (Northeast Spain). Earth and Planetary science letters 142: 381-396.

Garcés M, Krijgsman W, Peláez-Campomanes P, Àlvarez Sierra A, Daams R. 2003. Hipparion dispersal in Europe: magnetostratigraphic constraints from the Daroca area (Spain). Pp. 171-178 in: López-Martinez N, Peláez-Campomanes P, Hernández Fernández M, eds, En torno a fósiles de mamiferos: datación, evolución y paleoambiente. Coloquios de Paleontologia, Volumen Extroardinario 1.

Hír J, Kókay J, Venczel M. 2001. Middle Miocene molluscs and microvertebrata from Tăşad (Bihor County, Romania). Acta Paleontologica Romaniae 3: 161-172.

Hugueney M, Adrover R. 2003. Tetracus daamsi, une nouvelle espèce de Galericinae (Erinaceidae, Mammalia) dans l'Oligocène de Majorque (Espagne). Pp. 311-324 in: LópezMartinez N, Peláez-Campomanes P, Hernández Fernández 
M, eds, En torno a fósiles de mamiferos: datación, evolución y paleoambiente. Coloquios de Paleontologia, Volumen Extroardinario 1.

Kälin D. 1993. Stratigraphie und Säugetierfaunen der oberen Süsswassermolasse der Nordwestschweiz. Dissertation, Eidgenössischen Technischen Hochschule Zürich.

Kälin D, Engesser B. 2001. Die jungmiozäne Säugertierfauna vom Nebelbergweg bei Nunningen (Kanton Solothurn, Schweiz). Schweizerische Paläontologische Abhandlungen 121: 1-61.

Kälin D, Weidmann M, Engesser B, Berger JP. 2001. Paléontologie et âge de la Molasse d'eau douce supérieure (OSM) du Jura Neuchâtelois. Schweizerische Paläontologische Abhandlungen 121: 63-101.

Kuhlemann J. 2007. Paleogeographic and paleotopographic of the Swiss and Eastern Alps since the Oligocene. Global Planetary Change 58: 224-236.

Luis A, Hernando JM. 2000. Los microvertebrados del Miocene Medio de Somosaguas Sur (Pozuel de Alarcón, Madrid, Spain). Colloquios de Paleontologia 51: 87-136.

Maridet O. 2003. Révision du genre Democricetodon (Mammalia, Rodentia, Cricetinae) et dynamique des faunes de rongeurs du Néogène d'Europe occidentale: évolution, paléodiversité et paléogéographie. $\mathrm{PhD}$ Thesis, l'Université Claude-Bernard Lyon 1.

Markovic Z. 2003. The Miocene small mammals of Serbia, a review. Pp. 287-303 in: Reumer JWF, Wessels W, eds, Distribution and migration of Tertiary mammals in Eurasia. A volume in honour of Hans de Bruijn. Deinsea 10.

Mayr H, Fahlbusch V. 1975. Eine unterpliozäne Kleinsäugerfauna aus der Oberen Süßwasser-Molasse Bayerns. Mitteilungen der Bayerischen Staatssammlung für Paläontologie und historische Geologie 15: 91-111.

Mein P. 1999. European Miocene Mammal Biochronology. Pp. 25-38 in: Rössner G, Heissig K, eds, The Miocene Land Mammals of Europe. Munich: Dr. Friedrich Pfeil.

Mein P, Ginsburg L. 2002. Sur l'âge relatif des différents dépôts karstiques miocènes de la Grive-Saint-Alban (Isère). Cahiers scientifiques Muséum d'Histoire naturelle Lyon 2: 7-47.

Prieto J. 2007. Kleinsäuger-Biostratigraphie und Paläoökologie des höheren Mittelmiozäns (MN 8) Bayerns: Spaltenfüllungen der Fränkischen Alb und Lokalitäten der Oberen Süßwassermolasse im Vergleich. PhD thesis, LMU München.

Prieto J, Rummel M. 2009a. Erinaceidae (Mammalia, Erinaceomorpha) from the Middle Miocene fissure filling Petersbuch 68 (South Germany). Zitteliana 48/49: 103-111.

Prieto J, Rummel M. 2009b. Evolution of the genus Collimys Daxner-Höck, 1972. (Rodentia, Cricetidae). A key to Middle to Late Miocene biostratigraphy in Central Europe. Neues Jahrbuch für Geologie und Palaeontologie 252: 237-247.

Prieto J, Gross M, Böhmer C, Böhme M. 2010a. Insectivores and bat (Mammalia) from the late Middle Miocene of Gratkorn (Austria): biostratigraphic and ecologic implications. Neues Jahrbuch für Geologie und Paläontologie 258: 107-119.

Prieto J, Böhme M, Gross M. 2010b. The cricetid rodents from Gratkorn (Austria, Styria) - A benchmark locality for the continental Sarmatian s.str. (late Middle Miocene) in the central Paratethys. Geologica Carpathica 61: 419-436.

Rabeder R. 1973. Galerix und Lantanotherium (Erinaceidae, Insectivora) aus dem Pannon des Wiener Beckens. Neues Jahrbuch für Geologie und Paläontologie Monatshefte 7:
429-446

Rögl F, Daxner-Höck G. 1996. Late Miocene Paratethys correlations. Pp 47-55 in: Bernor RL, Fahlbusch V, Mittmann W, eds, The Evolution of Western Eurasian Neogene Mammal Faunas. Columbia Press 16.

Rzebik-Kowalska B. 1993. Insectivora (Mammalia) from the Miocene of Bełchatów, Poland. I. Metacodontidae: Plesiosorex Pomel, 1854. Acta Zoologica Cracoviensia 36: 267274.

Rzebik-Kowalska B. 1996. Insectivora (Mammalia) from the Miocene of Bełchatów, Poland. III. Dimylidae Schlosser, 1887. Acta Zoologica Cracoviensia 39: 447-468.

Rzebik-Kowalska B. 2005. Erinaceomorpha and Soricomorpha (Mammalia) from the Miocene of Belchatów, Poland. IV. Erinaceidae Fischer von Waldheim, 1817 and Talpidae Fischer von Waldheim, 1817. Acta Zoologica Cracoviensia A 48: 71-91.

Rzebik-Kowalska B, Lungu A. 2009. Insectivore mammals from the Late Miocene of the Republic of Moldava. Acta Zoologica Cracoviensia 52 A: 11-60.

Sabol M. 2005. Middle Miocene assemblage of insectivores from Bonanza site near Devínska Nová Ves (Slovakia). Geologica Carpathica 56: 433-445.

Sabol M, Joniak P, Holec P. 2004. Succession(-s) of mammalian assemblages during the Neogene - a case study from the Slovak part of the Western Carpathians. Scripta Facultatis Scientarium Naturalis Universitatis Masaryk, Brunensis 31-32: 65-84.

Schötz M. 1988. Die Erinaceiden (Mammalia, Insectivora) aus Niederaichbach und Maßendorf (Obere Süßwassermolasse Niederbayerns). Mitteilungen der bayerischen Staatsammlung für Paläontologie und historische Geologie 28: 65-87.

Selänne L. 2003. Genus Schizogalerix (Insectivora). Pp. 69-89 in: Fortelius M, Kappelman J, Sen S, Bernor RL, eds, Geology and Paleontology of the Miocene Sinap Formation. Turkey. New York: Columbia University Press.

Shevenell AE, Kennet JP, Lea DW. 2004. Middle Miocene Southern Ocean Cooling and Antarctic Cryosphere Expansion. Science 305: 1766-1770.

Steininger FF, Bergreen WB, Kent DV, Bernor RL, Sen S, Agusti J. 1996. Circum Mediterranean Neogene (Miocene and Pliocene) marine continental chronologic correlations of European mammal units and zones. Pp 7-46 in: Bernor RL, Fahlbusch V, Rietschel S, eds, Later Neogene European Biotic Evolution and Stratigraphic Correlation. Columbia University press.

Stromer E. 1940. Die jungtertiäre Fauna des Flinzes und des Schweiß-Sandes von München. Abhandlungen der Bayerischen Akademie der Wissenschaften, mathematisch-naturwissenschaftliche Abteilung, Neue Folge 48: 1-102.

Thenius E. 1949. Zur Revision der Insektivoren des steirischen Tertiärs. Sitzungsberichte der Kaiserlichen Akademie der Wissenschaften in Wien 158: 671-693.

Thenius E. 1952. Die Säugetierreste aus dem Jungtertiär des Hausruck und Kobernaußerwaldes (O.Österr.) und die Altersstellung der Fundschichten. Jahrbuch der Geologischen Bundesanstalt Wien 95: 119-144.

Tobien H. 1938. Über Hipparion-Reste aus der obermiozänen Süßwassermolasse Südwestdeutschlands. Zeitschrift der Deutschen Gesellschaft für Geowissenschaften 90: 177-192. 
Tobien H. 1982. Osteologische Bemerkungen zum Fußbau von Hipparion (Equidae, mammalia) aus der jungtertiären Wirbeltier-Fundstätte Höwenegg/Hegau (Baden-Württemberg, BRD). Zeitschrift für geologische Wissenschaften 10: 1043-1057.

Van Dam JA, Abdul Aziz H, Álvarez Sierra MÁ, Hilgen FJ, van den Hoek Ostende LW, Lourens LJ, Mein P, Meulen AJ van der, Pelaez-Campomanes P. 2006. Long-period astronomical forcing of mammal turnover. Nature 443: 687-691.

Van den Hoek Ostende LW. 2001. A revised generic classification of the Galericini (Insectivora, Mammalia) with some remarks on their palaeogeography and phylogeny. Geobios 34: 681-695.

Van den Hoek Ostende LW. 2003. Insectivores (Erinaceomorpha, Soricomorpha, Mammalia) from the Ramblian of the Daroca-Calamocha area. Pp. 281-310 in: López-Martinez N, Peláez-Campomanes P, Hernández Fernández M, eds, En torno a fósiles de mamiferos: datación, evolución y paleoambiente. Coloquios de Paleontología,Volumen Extraordinario 1

Van den Hoek Ostende LW, Doukas CS. 2003. Distribution and evolutionary history of the Early Miocene erinaceid Galerix symeonidisi Doukas, 1986. Pp. 287-303 in: Reumer JWF, Wessels W, eds, Distribution and Migration of the tertiary mammals in Eurasia. A volume in honour of Hans de Bruijn. Deinsea 10.

Van den Hoek Ostende LW, Furió M. 2005. Spain. Pp. 149-284 in: Van den Hoek Ostende LW, Doukas CS, Reumer JWF, eds, The Fossil Record of the Eurasian Neogene Insectivores (Erinaceomorpha, Soricomorpha, Mammalia), Part I. Scripta Geologica, Special Issue 5.

Van den Hoek Ostende LW, Fejfar O. 2006. Erinaceidae and Talpidae (Erinaceomorpha, Soricomorpha, Mammalia) from the Lower Miocene of Merkur-Nord (Czech Republic, MN 3). Beiträge zur Paläontologie 30: 175-203.

Van der Meulen AJ, Daams R. 1992. Evolution of Early-Middle Miocene rodent faunas in relation to long-term paleoenviromental changes. Palaeogeography, Palaeoclimatology, Palaeoecology 93: 227-253.

Van der Meulen AJ, Peláez-Campomanes P, Levin SA. 2005. Age structure, residents and transients of Miocene rodent communities. The American Naturalist 165: 108-125.

Ziegler PA, Dèzes P. 2007. Neogene uplift of Variscan Massifs in the Alpine foreland: Timing and controlling mechanisms. Global and Planetary Change 58: 237-269. doi: 10.1016/j.gloplacha.2006.12.004
Ziegler R. 1983. Odontologische und osteologische Untersuchungen an Galerix exilis (BLAINVILLE) (Mammalia, Erinaceidae) aus den miozänen Ablagerungen von Steinberg und Goldberg im Nördlinger Ries (Süddeutschland). PhD Thesis, Ludwig-Maximillians-Universität München.

Ziegler R. 2000. The Miocene Fossil-Lagerstätte Sandelzhausen: 17. Marsupiala, Lipotyphla and Chiroptera (Mammalia). Senckenbergiana Lethaea 80: 81-127.

Ziegler R. 2003. Insektenfresser (Lipotyphla) aus dem MittelMiozän von Mühlbach am Manhartsberg und Grund, Niederösterreich. Annalen des Naturhistorischen Museums in Wien 104 A: 251-265.

Ziegler R. 2005. Erinaceidae and Dimylidae (Lipotyphla) from the Upper Middle Miocene of South Germany. Senckenbergiana Lethaea 85: 131-152.

Ziegler R. 2006a. Miocene Insectivores from Austria and Germany - An Overview. Beiträge zur Paläontologie 30: 481494.

Ziegler R. 2006b. Insectivores (Lipotyphla) and Bats (Chiroptera) from the Late Miocene of Austria. Annalen des Naturhistorischen Museums in Wien 107 A: 93-106.

Ziegler R, Fahlbusch V. 1986. Kleinsäuger-faunen aus der basalen Oberen Süßwasser-Molasse Niederbayerns. Zitteliana 14: 3-58.

Ziegler R, Dahlmann T, Reumer JWF, Storch G. 2005. Germany. Pp. 61-98 in: van den Hoek Ostende LW, Doukas CS, Reumer JWF, eds, The Fossil Record of the Eurasian Neogene Insectivores (Erinaceomorpha, Soricomorpha, Mammalia) Part I. Scripta Geologica, Special Issue 5.

Ziegler R, Daxner-Höck, G. 2005. Austria. Pp. 11-29 in: van den Hoek Ostende LW, Doukas CS, Reumer JWF, eds, The Fossil Record of the Eurasian Neogene Insectivores (Erinaceomorpha, Soricomorpha, Mammalia) Part I. Scripta Geologica, Special Issue 5.

Ziegler R, Mörs T. 2000. Marsupialia, Lipotyphla und Chiroptera (Mammalia) aus dem Miozän des Braunkohlentagebaus Hambach (Niederrheinische Bucht, NW-Deutschland). Palaeontographica A 257: 1-26.

Received: 4 November 2010

Revised and accepted: 8 March 2011

Published online: 15 July 2011

Editor: M. Brazeau 
